\title{
PEMBATALAN PADA PERJANJIAN \\ YANG TIDAK MENGGUNAKAN BAHASA INDONESIA \\ (STUDI KASUS PUTUSAN NOMOR 450/PDT.G/2012 / PN.JKT.BAR)
}

\author{
Thomas Aryanto G \\ (Mahasiswa Program S1 Fakultas Hukum Universitas Tarumanagara) \\ (E-mail: Thomas.Aryanto28@Gmail.com)
}

\section{S Atalim}

(Corresponding Author)

(Dosen Hukum Perusahaan Fakultas Hukum Universitas Tarumanagara, Meraih Sarjana Hukum dari

Fakultas Hukum Universitas Indonesia, Magister Hukum dari Fakultas Hukum Universitas Indonesia,

Doktor Hukum dari Fakultas Hukum Universitas Parahyangan)

(E-mail: St_Atalim@Yahoo.Com)

\begin{abstract}
Starting from the treaty agreement from national agreement to international agreement, with the existence of the development of the time of course there are many developments including in the development in the field of agreement. in this journal the author explains about how should the implementation of Article 31 of Law Number 24 Year 2009 concerning about Flags, Languages, and Symbol of Country and National Anthem should be applied in Indonesia. the authors raise this issue using case studies on decision number 450 / Pdt.G / 2012 / PN Jkt.Bar where PT Bangun Karya Pratama Lestari sued Nine AM Ltd. to cancellation agreements that only use the English language without using the Indonesian language. in this case the panel of judges decides that the agreement is null and void because it violates Article 31 of Law Number 24 Year 2009 because the judges consider the agreement to violate Article 1320 Paragraph (4) of the Civil Code which reads "a lawful cause" this article of judges misinterpreted the exclusion of the law on the promulgation of the treaty. in the old legal books says that is not to violate the law is to the purpose of making a treaty not on the written evidence of a covenant that is only evidence when there is a dispute between the covenant makers. a covenant is not a written matter but the treaty itself is an agreement executed and agreed upon by both parties to fulfill the agreed agreement.
\end{abstract}

Keywords :Agreement, Written Prof of Agreement 


\section{PENDAHULUAN}

\section{A. Latar Belakang}

Hukum bertujuan mengatur berbagai kepentingan manusia dalam rangka pergaulan hidup di masyarakat.kepentingan manusia dalam masyarakat begitu luas, mulai dari kepentingan pribadi hingga masyarakat dengan Negara. Untuk itu pergolongan hukum privat mengatur kepentingan individu atau pribadi, seperti hukum dagang dan hukum perdata. Hukum perikatan yang terdapat dalam buku III kitab undang-undang hukum perdata merupakan hukum yan bersifat khusus dalam melakukan perjanjian dan perbuatan hukum yang bersifat ekonomis atau perbuatan hukum yang dapat dinilai dari harta kekayaan seseorang atau badan hukum.

Dalam kegiatan ekonomi terdapat upaya untuk mendapatkan keuntungan atau laba. Namun harus berdasarkan peraturan dan norma yang terdapat dalam undangundang yang berlaku maupun hukum yang berlaku. Dengan adanya hubungan hukum maka terjadi pertalian hubungan subjek hukum dengan objek hukum (hubungan hak kebendaan). Dalam hukum perjanjian didalamnya terdapat dua azas yaitu azas konsensualitas dan azas kebebasan berkontrak.

Dalam perkembangan perekonomian di Indonesia, tentunya memerlukan perangkat hukum nasional yang sesuai dengan hukum perikatan atau kontrak yang berkembang dinamis dalam masyarakat melengkapi perangkat perundang-undangan. Di Indonesia berbagai peratutran undang-undang dibuat oleh pemerintah Indonesia telah menggantikan sebagian kitab undang-undang hukum perdata dan kitab undangundang hukum dagang. Naumun untuk mengisi kekosongan hukum di Indonesia maka ke dua kitab undang-undang itu masih digunakan sampai ada peraturan perundang-undangan yang baru untuk menggantinya.

Ketentuan Pasal 1233 ayat (1) Kitab Undang-Undang Hukum Perdata menyatakan bahwa "Tiap-tiap perikatan dilahirkan, baik karena suatu persetujuan, maupun kerena undang-undang". Pernyataan ini membawa konsekuensi bahwa hubungan hukum yang menerbitkan kewajiban atau prestasi dalam lapangan harta kekayaan dapat terjadi dari perbuatan hukum. Perbuatan hukum tersebut dapat 
merupakan suatu perbuatan hukum yang tidak dikehendaki dan direncanakan oleh para pihak yang terkait dalam perikatan tersebut oleh para pihak dalam perikatan tersebut. ${ }^{1)}$ Misalnya dalam perikatan yang lahir dari jual beli, kewajiban penjual untuk menyerahkan barang yang dijual, dan kewajiban pembeli untuk membayar harga barag yang dibeli adalah perikatan yang lahir karena perbuatan hukum yang dikehendaki oleh para pihak, baik pembeli maupun penjual.

Sedangkan perikatan yang lahir dari perbuatan hukum yang tidak dikehendaki dapat ditemukan dalam perbuatan melawan hukum, misalnya seorang karena kelalaiannya dalam mengemudikan kendaraan telah menabrak pagar milik orang lain hingga rusak. Atas perbuatan hukum menabrak pagar hingga rusak ini terbit perikatan, yang melahirkan kewajiban dari orang yang menabrak untuk memberikan ganti kerugian berupa perbaikan pagar. Perbuatan hukum yang menyebabkan kerugian ini adalah perbuatan hukum yang tidak dikehendaki baik oleh penabrak maupun pemilik pagar yang ditabrak.

Dalam beberapa tahun terakhir perjanjian yang dilakukan di dalam masyarakat terus berkembang. Dengan berkembangnya perjanjian ini mengakibatkan munculnya perjanjian-perjanjian yang sangat digunakan dalam kegiatan bisnis seperti Loan Agreement atau Perjanjian Pinjam Meminjam adalah persetujuan dengan mana pihak yang satu memberikan kepada pihak yang lain suatu jumlah tertentu barang-barang yang menghabis karena pemakaian dengan syarat bahwa pihak yang belakangan ini akan mengembalikan sejumlah yang sama dari macam dan keadaan yang sama pula. ${ }^{2)}$

Seiring berkembangnya jaman tidak jarang pula terjadinya hukum perdata internasional atau melewati batas negara. Tidak jarang salah satu pihak tidak mengetahui hukum yang berlaku dalam negara lain. Terkait dengan Loan Agreement, tentunya para pihak membutuhkan perlindungan guna melindungi hak-haknya. Menurut Pasal 1338 KUHPerdata mengatakan semua persetujuan yang dibuat sesuai

1) Kartini Muljadi dan Gunawan Widjaja, Perikatan Pada Umumnya, (Jakarta: PT RajaGrafindo Persada, 2004), hal. 41.

2) Indonesia, Kitab Undang-Undang Hukum Perdata, Pasal 1754 
dengan undang- undang berlaku sebagai undang-undang bagi mereka yang membuatnya. Persetujuan itu tidak dapat ditarik kembali selain dengan kesepakatan kedua belah pihak, atau karena alasan-alasan yang ditentukan oleh undang-undang. Persetujuan harus dilaksanakan dengan itikad baik. ${ }^{3)}$ Selain itu Syarat perjanjian juga merupakan hal penting dalam membuat suatu perjanjian yang terkandung di dalam Pasal 1320 KUHPerdata yang berbunyi "Supaya terjadi persetujuan yang sah, perlu dipenuhi empat syarat; 1. Kesepakatan mereka yang mengikatkan dirinya; 2. Kecakapan untuk membuat suatu perikatan; 3. Suatu pokok persoalan tertentu; 4. Suatu sebab yang tidak terlarang."

Peraturan mengenai perdata internasional juga merupakan bagian tak terpisahkan dari kegiatan bisnis yang sehat. Dalam kegiatan bisnis yang sehat terdapat keseimbangan perlindungan hukum antara para pihak. Pasal 16 A.B. berbunyi:"De wettelijke bepalingen betreffende den staat en de voegdheid der personen blijven verbindend voor ingezetenen van Nederlandsch-Indie, wanneer zij zich buiten's lands bevinden.". Terjemahannya: "Bagi penduduk Hindia-Belanda peraturan-peraturan perundang-undangan mengenai status dan wewenang seseorang tetap berlaku terhadap mereka, apabila mereka ada di luar negeri." Pasal ini sesuai dengan statuta personalia, yang mencakup: 1. Peraturan mengenai hukum perorangan (personenrecht). Termasuk hukum kekeluargaan. 2. Peraturan-peraturan mengenai benda yang tidak tetap (bergerak). Termasuk kewenangan seseorang dalam membuat perjanjia tetapi tidak adanya perlindungan yang seimbang menyebabkan pihak negara luar berada pada posisi yang lemah. Kerugian-Kerugian yang dialami oleh investor asing dapat timbul sebagai akibat dari adanya hubungan hukum perjanjian antara investor asing dengan investor lokal, maupun akibat dari adanya itikat tidak baik yang dilakukan oleh investor lokal.

3) Indonesia, Kitab Undang-Undang Hukum Perdata, Pasal 1338.

4) Indonesia, Kitab Undang-Undang Hukum Perdata, Pasal 1320. 
Syarat sahnya perjanjian sebagaimana dijelaskan pada paragraph sebelumnya sering kali dijadikan senjata bagi pihak-pihak yang cenderung melanggar janjinya. Sebagai contoh dalam kasus yang penulis ambil kali ini yaitu perselisihan antara PT Banguna Karya Pratama (BKP) melawan Nine AM Ltd. Disebutkan dalam pembelaan Tergugat yakni Nine AM Ltd yang digugat dalam kasus ini hanyalah mengenai bahasa yang esensinya untuk kenyamanan para pihak dalam membaca kontrak perjanjian dan dapat diubah sewaktu-waktu. Sehinga sebetulnya UndangUndang tidak mengatur secara detil bahwa Perjanjian akan batal demi hukum bila tidak berbahasa Indonesia.

Padahal dalam hal ini, dalam ketentuan Pasal 31 Undang- Undang No.24 Tahun 2009 tentang Bendera, Bahasa, Serta Lagu Kebangsaan tersebut tidak mengatur bahwa apabila Perjanjian tidak disusun dalam Bahasa Indonesia maka dapat dibatalkan, atau tidak ada satupun ketentuan dalam Undang-Undang Nomor 24 Tahun 2009 tentang Bendera, Bahasa, Dan Lambang Negara Serta Lagu Kebangsaan yang dapat mengubah syarat sahnya Perjanjian sebagaimana Pasal 1320 Kitab UndangUndang Hukum Perdata. ${ }^{5)}$

Seperti diketahui, NINE AM LTD (“Tergugat”), sebuah badan hukum yang berdiri berdasarkan Hukum negara bagian Texas, Amerika Serikat merupakan salah satu perusahaan yang dirugikan karena adanya itikad tidak baik yang dilakukan PT Bangun Karya Pratama Lestari ("Penggugat") yang menyebabkan pembatalan perjanjian yang terjadi di depan pengadilan. Penggugat menggugat Tergugat setelah terjadinya wanprestasi yang dilakukan oleh Penggugat. Dalam perjanjian ini pada bagian Hukum Yang Mengatur Dan Domisili Hukum menentukan bahwa "Perjanjian ini diatur oleh dan ditafsirkan menurut hukum yang berlaku di Republik Indonesia. Mengenai Perjanjian ini dan segala akibatnya, Debitur memilih domisili hukum tetap di Kantor Panitra Pengadilan Negeri Jakarta Barat”. Meskipun perjanjian tunduk pada hukum Indonesia tetapi perjanjian dibuat dalam bahasa Inggris.

${ }^{5)}$ Subekti, Hukum Perjanjian, (Jakarta: Intermasa, 2005), hal 25. 
Gugatan ini bermula dari sebuah perjanjian, Loan Agreement tertanggal 23 April 2010. Perjanjian tersebut mengatur Penggugat memperoleh pinjaman dana dari Tergugat sejumlah AS\$4,422 juta. Perjanjian tersebut dibuat dan tunduk pada ketentuan hukum yang berlaku di Indonesia. Sebagai jaminan utang, para pihak membuat akta perjanjian jaminan fidusia atas benda tertanggal 27 April 2010, benda yang dijaminkan berupa enam unit Truck Caterpillar Model 775F Off Highway. Dengan mekanisme pembayaran tersebut selama 48 kali angsuran bulanan sebesar AS $\$ 148,5$ ribu per bulan dan bunga akhir AS $\$ 1,8$ juta yang wajib dibayarkan pada tanggal pembayaran akhir angsuran pinjaman.

Setelah berjalan selama dua tahun, Penggugat mengajukan gugatan karena menurutnya perjanjian tersebut tidak memenuhi syarat formil. Perjanjian tersebut dinilai melanggar Pasal 31 Ayat (1) Undang-Undang Nomor 24 Tahun 2009 tentang Bendera, Bahasa dan Lambang Negara Serta Lagu Kebangsaan. Dikarenakan kontrak tersebut dibuat dalam Bahasa Inggris, tanpa menggunakan Bahasa Indonesia.

Dalam Gugatannya Penggugat meminta pengadilan untuk menyatakan kontrak tersebut batal demi hukum atau setidak-tidaknya dinyatakan tidak memiliki kekuatan mengikat. Gugatan Nomor 450/Pdt.G/2012/PN.Jkt.Bar ini dikabulkan majelis hakim yang dalam putusannya menyatakan perjanjian tersebut memang bertentangan dengan Pasal 31 Ayat (1) Undang-Undang Nomor 24 Tahun 2009 tentang Bendera, Bahasa, Dan Lambang Negara Serta Lagu Kebangsaan, selain itu majelis juga memerintahkan Penggugat untuk mengembalikan semua pinjaman yang telah diberikan Tergugat karena telah membayar AS\$3.504.460 ditambah deposit AS\$800 ribu majelis meminta Penggugat mengembalikan sisa uang Tergugat sebanyak AS\$115.540.

Atas putusan ini Tergugat tidak puas dan bersikukuh dan berpandangan bahwa Undang-Undang Nomor 24 Tahun 2009 tentang Bendera, Bahasa, Dan Lambang Negara Serta Lagu Kebangsaan tidak mengatur sanksi berupa pembatalan atas suatu perjanjian yang tidak dibuat dalam Bahasa Indonesia. Pihak Tergugat pun terus melakukan upaya hukum banding dan kasasi yang hasilnya hanya menguatkan putusan pengadilan dibawahnya. 
Dikatakan dalam Pasal 31 Ayat (1) Undang-Undang Nomor 24 Tahun 2009 tentang Bendera, Bahasa, Dan Lambang Negara Serta Lagu Kebangsaan Bahasa Indonesia wajib digunakan dalam nota kesepahaman atau perjanjian yang melibatkan lembaga negara, instansi pemerintah ${ }^{\text {Republik }}$ Indonesia, lembaga swasta Indonesia atau perseorangan warga negara Indonesia.

Dengan adanya gugatan dari Penggugat dengan alasan tidak memenuhi syarat formil tertentu menyebabkan Loan Agreement dinyatakan batal demi hukum atau setidak-tidaknya tidak memiliki kekuatan hukum mengikat tentu saja hal ini sangat merugikan Tergugat.

Padahal dalam hal ini, dalam ketentuan Pasal 31 Ayat (1) Undang-Undang Nomor 24 Tahun 2009 tentang Bendera, Bahasa, Dan Lambang Negara Serta Lagu Kebangsaan tidak mengatur bahwa apabila Perjanjian tidak disusun dalam Bahasa Indonesia maka dapat dibatalkan, atau tidak ada satupun ketentuan dalam UndangUndang Nomor 24 Tahun 2009 tentang Bendera, Bahasa, Dan Lambang Negara Serta Lagu Kebangsaan yang dapat mengubah syarat sahnya Perjanjian sebagaimana Pasal 1320 Kitab Undang-Undang Hukum Perdata.

Hal tersebutlah yang menjadi alasan yang mendorong penulis untuk melakukan penelitian dalam rangka penyusunan jurnal hukum, yang berjudul: "Pembatalan Pada Perjanjian Yang Tidak Menggunakan Bahasa Indonesia (Studi Kasus Putusan Nomor 450/Pdt.G/2012 / Pn.Jkt.Bar)"

\section{B. Permasalahan}

Berdasarkan Berdasarkan uraian latar belakang, yang telah dituliskan pada bagian sebelumnya, maka penulis mengambil permasalahan yang akan diteliti dalam penelitian ini adalah apakah pertimbangan dasar hukum hakim sudah tepat dilihat dari ilmu perundang-undangan pada kasus putusan Nomor 450/Pdt.G/2012 / Pn.Jkt.Bar? 


\section{Metode Penelitian}

Metode penelitian hukum merupakan suatu proses untuk menemukan aturan hukum, prinsip-prinsip hukum, maupun doktrin-doktrin hukum guna menjawab isu hukum yang akan dihadapi.

\section{Tipe Penelitian}

Ilmu hukum mempunyai karakter yang khas, yaitu sifatnya yang normatif, praktis, dan preskriptif. "Sebagai ilmu yang bersifat preskriptif, ilmu hukum mempelajari tujuan hukum, nilai-nilai keadilan, validitas aturan hukum, konsepkonsep hukum, dan norma-norma hukum. Sebagai ilmu terapan, ilmu hukum menetapkan standar prosedur, ketentuan-ketentuan, rambu-rambu dalam melaksanakan aktifitas hukum". ${ }^{6)}$ Penelitian yang dikaji penulis dalam penelitian ini merupakan penelitian yang bersifat normatif, yang dimaksudkan untuk memberikan argumentasi atas hasil penelitian yang telah dilakukan.

Menurut Peter Mahmud Marzuki, penelitian hukum adalah kegiatan know-how dalam ilmu hukum, bukan sekadar know-about. Sebagai kegiatan know-how, kegiatan ini dilakukan untuk memecahkan problem hukum yang dihadapi. ${ }^{7)}$ Di sinilah dibutuhkan kemampuan untuk mengidentifikasi masalah hukum, melakukan penalaran hukum, menganalisis persoalan hukum yang dihadapi, dan memberikan pemecahan atas masalah tersebut.

\section{Jenis dan Sumber Data}

Untuk memecahkan problem-problem hukum perdata, dalam penelitian ini penulis menggunakan sumber penelitian yang bersifat primer maupun yang bersifat sekunder.

a. Sumber Primer

Sumber hukum primer merupakan bahan hukum yang mengikat atau yang membuat masyarakat taat pada hukum seperti peraturan perundang-

6) Peter Mahmud Marzuki,Penelitian Hukum, (Jakarta: Prenada Media Group,2016), hal 59.

7) $I$ bid. 
undangan dan putusan hakim. Bahan hukum primer yang penulis gunakan di dalam penelitian ini mengacu pada Kitab Undang-Undang Hukum Perdata dan Undang-Undang Nomor 24 Tahun 2009 tentang Bendera, Bahasa, Dan Lambang Negara Serta Lagu Kebangsaan dan Putusan Nomor 450/Pdt.G/2012 / Pn.Jkt.Bar. Dari penjelasan di atas yang dapat dijadikan bahan hukum primer adalah berupa legislasi dan regulasi.

b. Sumber Sekunder

Bahan hukum sekunder memang tidak mengikat, tetapi menjelaskan mengenai bahan hukum primer yang merupakan pendapat atau pikiran para pakar yang mempelajari suatu bidang tertentu secara khusus. Pendapat ini akan memberikan petunjuk ke mana penelitian akan mengarah. Bahan hukum sekunder adalah doktrin-doktrin yang ada di dalam buku, dan internet yang berhubungan dengan perjanjian dan hukum perdata internasional.

Bahan buku sekunder terutama adalah buku-buku hukum termasuk skripsi, tesis, dan jurnal-jurnal hukum, kamus-kamus hukum, juga komentar atas putusan pengadilan. Tulisan seperti skripsi dan artikelartikel hukum bisa memberi inspirasi bagi peneliti untuk menjadi titik anjak dalam memulai penelitian. Bagi para praktisi hakim, bahan hukum ini sangat mungkin menjadi panduan berfikir dalam penyusunan argumentasi yang akan diajukan dalam persidangan atau memberikan pendapat hukum. ${ }^{8)}$

Tentu saja, buku-buku dan artikel hukum yang dirujuk adalah yang mempunyai relevansi dengan apa yang hendak diteliti. Begitu juga dengan komentar-komentar atas putusan pengadilan perlu diseleksi kasus-kasus yang relevan dengan objek penelitian. Membicarakan warisan dari suatu

${ }^{8)}$ Ibid., hal. 196. 
perkawinan campur tentu tidaklah relevan membaca buku-buku yang membicarakan hukum pidana. ${ }^{9)}$

c. Sumber 'Nonhukum'

Peter Mahmud Marzuki menjelaskan materi kuliah hukum, presentasi dalam seminar, pembicaraan secara lisan, dialog di televise, radio, wawancara, jika dasarnya adalah bahan tertulis atau kemudian pendapat lisan itu diterbitkan dalam bentuk tulisan atau buku, maka disebut sumber hukum sekunder, sementara wawancara yang semata-mata lisan, tidak diterbitkan dalam bentuk tulisan, tetapi dipakai sebagai rujukan, maka disebut 'nonhukum'. 10)

\section{Pendekatan}

Pendekatan skripsi ini, Penulis menggunakan pendekatan Undang-Undang dan studi kasus. Pendekatan Undang-Undang adalah pendekatan yang dilakukan dengan menelaah semua Undang-Undang dan regulasi yang bersangkutan paut dengan isu hukum yang sedang ditangani. ${ }^{11)}$ Pendekatan Undang-Undang ini perlu memahami mengenai Jabatan Notaris, serta doktrin-doktrin yang mengacu pada isu hukum yang ditelaah. Studi kasus merupakan suatu studi terhadap kasus tertentu dari berbagai aspek hukum. $^{12)}$

\section{Teknik Pengumpulan dan Pengolahan Data}

Teknik Pengumpulan data yang digunakan dalam penulisan ini adalah dengan studi pustaka terhadap bahan-bahan hukum, baik bahan hukum primer, bahan hukum sekunder dan bahan non-hukum. Penelusuran bahan-bahan hukum tersebut dapat dilakukan dengan membaca, melihat, mendengarkan, maupun melalui media internet. $^{13)}$

\footnotetext{
9) Ibid., hal. 205.

${ }^{10)}$ Ibid., hal. 206.

${ }^{11)}$ Peter Mahmud Marzuki, Op. Cit., hal. 133.

${ }^{12)}$ Ibid., hal.134.

${ }^{13)}$ Mukti Fajar ND dan Yulianto Achmad, Op. Cit., hal.160.
} 
Setelah data dan bahan hukum dikumpulkan, tahap selanjutnya adalah melakukan pengolahan data, yaitu mengelola data sedemikian rupa sehingga data dan bahan hukum tersebut tersusun secara runtut dan sistematis. ${ }^{14)}$ Pada penelitian hukum normatif, pengelolaan bahan bertujuan untuk mengadakan sistematis terhadap bahanbahan hukum tertulis dengan cara melakukan seleksi data sekunder dan bahan hukum, kemudian melakukan klarifikasi menurut penggolongan bahan hukum dan menyusun data hasil penelitian tersebut secara sistematis dan logis.

\section{Tenik Analisa Data}

Hasil pengelolaan data tersebut dianalisis dengan teori yang didapatkan sebelumnya. ${ }^{15)}$ Teknik analisis data yang digunakan dalam penelitian ini adalah penelitian hukum yang bersifat preskriptif. Penelitian preskriptif, Penulis akan memberikan argumentasi atas hasil yang diperoleh melalui sumber-sumber penelitian. Argumentasi tersebut berupa penilaian mengenai benar atau salahnya, atau apa yang seyogyanya menurut hukum terhadap fakta atau peristiwa hukum dari hasil penelitian.

\section{PEMBAHASAN}

\section{A. Hasil Penelitian}

\section{Profil KASUS}

Pt. Bangun Karya Pratama Lestari beralamat di Sentra Niaga Puri Indah Blok T.3 No.1, Puri Kembangan, Jakarta Barat, yang diwakili oleh Andi Sutedja sebagai Direktur Utama, dalam perkara ini diwakili Kuasa Hukumnya Antawirya Jaya, SH. MH, Jimmy G.P Silalahi, SH para Advokat pada kantor Hukum Antawirya \& Associates beralamat di Wisma Nugraha Lt.4 Jl.Raden Saleh No.6 Jakarta Pusat 10430,, selanjutnya disebut sebagai PENGGUGAT, mengajukan Gugatan terhadap:

\footnotetext{
14) Peter Mahmud Marzuki, Op. Cit., hal.180.

${ }^{15)}$ Mukti Fajar ND dan Yulianto Achmad, Op. Cit., hal.183.
} 
NINE AM LTD, beralamat di 16031 East Freeway, Channelview, Texas 77530 USA, dalam perkara ini diwakili Kuasa Hukumnya Emir Kusumaatmadja, SH. LLM dkk para Advokat berkantor di Mochtar Karuwin Komar alamat Wisma Metropolitan II Lantai 14 J1. Jend. Sudirman Kav. 31 Jakarta 12920, selanjutnya disebut TERGUGAT.

Hubungan hukum yang terjadi antara penggugat (Pt Bangun Karya Pratama Lestari) dengan tergugat (NINE AM LTD.) didasarkan atas adanya loan agreement tertanggal 30 juli 2010.

Bahwa berdasarkan Loan Agreement / Perjanjian Pinjam Meminjam tertanggal 30 Juli 2010 yang dibuat oleh dan antara PENGGUGAT dengan TERGUGAT,(berdasarkan Loan Agreement yang telah diterjemahkan ke dalam bahasa Indonsesia oleh Penterjemah Resmi dan Tersumpah) (selanjutnya disebut sebagai “Loan Agreement”), PENGGUGAT telahmemperoleh pinjaman uang dari TERGUGAT sebesar US\$ 4,999,500 (empat juta sembilan ratus sembilan puluh sembilan ribu lima ratus Dollar Amerika Serikat).

BahwaPasal 18 Loan Agreement perihal Hukum Yang Mengatur Dan Domisili Hukum, menentukan bahwa :

"Perjanjian ini diatur oleh dan ditafsirkan menurut hukum yang berlaku di Republik Indonesia. Mengenai Perjanjian ini dan segala akibatnya, Debitur memilih domisili hukum tetap di Kantor Panitera Pengadilan Negeri Jakarta Barat"

Bahwa sekalipun Loan Agreement tersebut dibuat dan ditandatangani serta tunduk pada ketentuan-ketentuan hukum yang berlaku di Indonesia, namunbahasa yang digunakan pada Loan Agreement tersebut adalah bahasa Inggris. Hal ini terjadi karena semua yang mempersiapkan Loan Agreementtersebut adalah pihakTERGUGAT, dimana PENGGUGAT tinggal menandatangani saja Loan Agreement. Bahkan Loan Agreement yang telah ditandatangani tersebut, baru PENGGUGAT peroleh dari TERGUGAT, (kurang lebih) 1 (satu) tahun kemudian; 
Bahwa sebagai Jaminan atas hutang tersebut, antara PENGGUGATdengan TERGUGAT, telah dibuat Akta Perjanjian Jaminan Fidusia Atas Benda tertanggal 30 Juli 2010 Nomor 77yang dibuat dihadapan Notaris \& PPAT di Jakarta.

Bahwa benda atau barang yang dijadikan jaminan secara fidusia tersebut adalah berupa 5 Unit Truck Caterpillar Model 777 D dengan nomer seri masingmasing berturut-turut, FKR 00635, FKR OO636,FKR 00637, FKR 00638 dan FKR 4064(selanjutnya barang jaminan fidusia ini disebut sebagai “Alat”);

Bahwa Pasal 2.1 Loan Agreement menentukan bahwa Pelunasanatau Pembayaran Kembali Pinjaman Beserta Bunganya Akan Dilakukan Sebagai Berikut:

(a) 48 kali angsuran bulanan sebesar US\$179,550 (serratus tujuhpuluh sembilan ribu lima ratus lima puluh rupiah) per bulan,sebagaimana dimaksud dalam Lampiran 1,dimana angsuran pertama wajib dibayar satu bulan setelah tanggal transfer pinjaman ke rekening Debitur sebagaimana dijelaskan dalam Pasal 1 di atas, sedangkan angsuran sisanya akan menyusul setelahnya;

(b) Pembayaran bunga akhir sebesar US\$ 1,500,000 (satu juta lima ratus ribu Dolar Amerika Serikat) yang wajib dibayar pada tanggalpembayaran terakhir angsuran pinjaman;

Bahwa setelah Majelis Hakim memerintahkan para pihak dalam perkara a quo untuk melakukan mediasi yang berlangsung mulai tanggal 8 Oktober 2013 sampai dengan tanggal 6 November 2013, para pihak tidak mencapai kesepakatan dalam mediasi tersebut sehingga agenda persidangan dilanjutkan dengan agenda jawabmenjawab antara para pihak.

Dengan hakim menimbang putusan sebagai berikut :

1) Menimbang, bahwa maksud dan tujuan gugatan Penggugat sebagaimana diuraikan dimuka;

2) Menimbang, bahwa yang menjadi pokok gugatan Penggugat dalam perkara ini ialah mengenai hal sebagaimana yang dituntut dalam petitum pada angka 2 yaitu menuntut agar “ Menyatakan bahwa Loan 
Agreement tertanggal 30 Juli 2012 yang dibuat oleh dan antara PENGGUGAT dengan TERGUGAT, batal demi hukum atau setidak tidaknya tidak memiliki kekuatan hukum mengikat ( Null and void atau void ab initio; Nieteg )" ;

3) Menimbang, bahwa berdasarkan ketentuan Pasal 1320 KUH Perdata bahwa sahnya perjanjian perjanjian diperlukan empat syarat Bahwa,syarat pada angka 1 dan angka 2 tersebut adalah merupakan syarat Non essensial subyektif, yang apabila tidak dipenuhi maka perjanjian tersebut berakibat dapat dibatalkan, sedang syarat pada angka 3 dan 4 tersebut adalah merupakan syarat Essensial / obyektif, yang apabila tidak dipenuhi maka berakibat perjanjian tersebut batal demi hukum;

4) Menimbang, bahwa Penggugat, dalam surat gugatannya mendalilkan bahwa Loan Agreement tertanggal 30 Juli 2010, yang ditanda tangani oleh Penggugat dan Tergugat tersebut, sebelumnya telah dipersiapkan oleh Tergugat terlebih dahulu, sedang pihak Penggugat tinggal menanda tangani saja;

5) Bahwa, Loan Agreement tertanggal 30 Juli 2010 yang telah ditanda tangani oleh Penggugat dan Tergugat tersebut baru diterimakan/diserahkan kepada Penggugat setahun setelah penanda tanganan;

6) Bahwa, hal hal yang dilakukan oleh Tergugat sebagaimana yang telah diuraikan tersebut diatas, jelas telah melanggar ketentuan Pasal 31 ayat (1) UU.No.24Tahun 2009 tentang Bendera, Bahasa, Lambang Negara dan Lagu Kebangsaan, juga melanggar ketentuan pasal $1335 \mathrm{KUH}$ Perdata jo Pasal 1337 KUH Perdata;

7) Menimbang, bahwa atas dalil gugatan Penggugat tersebut, Tergugat telah menyangkal, yang pada intinya adalah sebagai berikut: 
a) Bahwa,Hubungan hukum antara Pengugat (Peminjam) dan Tergugat (Pemberi Pinjaman) adalah berdasarkan Perjanjian Pinjam Meminjam (Loan Agreement);

b) Bahwa, Gugatan Penggugat tidak berdasar, karena Perjanjian Pinjam Meminjam (Loan Agreement) tanggal 30 juli 2010 tidak bertentangan dengan Undang Undang Nomor 24 tahun 2009 tentang Bendera, Bahasa, Lambang Negara dan Lagu Kebangsaan ;

c) Bahwa, Gugatan Penggugat tidak berdasar, karena Perjanjian Pinjam Meminjam (Loan Agreement) tanggal 30 Juli 2010 telah sesuai dengan Undang Undang, Ketertiban Umum dan Kesusilaan ;

d) Bahwa, Gugatan Penggugat tidak berdasar, karena Pinjaman Uangyang diberikan Tergugat kepada Penggugat tidak tunduk pada ketentuan Perpres No.36 tahun 2010 Jo UU.No.25 tahun 2007 ;

8) Menimbang, bahwa Undang Undang Nomor 24 tahun 2009 tentang Bendera, Bahasa, Lambang Negara dan Lagu Kebangsaan tersebut diundangkan pada tanggal 9 Juli 2009, sehingga dengan demikian kekuatan mengikat berlakunya undang undang tersebut ada sejak tanggal diundangkan dan oleh karena itu setiap kesepahaman atau Perjanjian yang melibatkan Negara, Instansi Pemerintah Republik Indonesia, lembaga Swasta Indonesia dan Perseorangan Warga Negara Indonesia yang dibuat sesudah tanggal diundangkannya UU No.24 tahun 2009 tersebut yang tidak menggunakan Bahasa Indonesia adalah bertentangan dengan UU.No.24 tahun 2009;

9) Menimbang, bahwa hal tersebut tidaklah dapat menghapuskan ketentuan dalam undang undang No.24 tahun 2009 tersebut yang mewajibkan setiap kesepahaman atau Perjanjian yang melibatkan 
Negara, Instansi Pemerintah Republik Indonesia, lembaga Swasta Indonesia dan PerseoranganWarga Negara Indonesia wajib menggunakan bahasa Indonesia, karena suatu Peraturan Presiden mempunyai kedudukan yang lebih rendah dari Undang Undang, dan ketentuan dalam Peraturan Presiden tersebut tidak boleh bertentangan dengan ketentuan yang ada diatasnya demikian pula dengan surat Menteri Hukum dan HAM RI. No.M.HH.UM.01.01.35 tanggal 28 Desember 2009, yang dijadikan dasar dan alasan Tergugat

10) Menimbang, bahwa dengan tidak terpenuhinya salah satu syarat essensial dari syarat sahnya suatu perjanjian, sebagaimana ditentukan dalam ketentuan Pasal 1320 KUH Perdata, maka dengan demikian Perjanjian/Loan Egreement tertanggal 30 Juli 2010 yang telah ditanda tangani oleh Penggugat dan Tergugat adalah Batal Demi Hukum;

\section{B. Analisa}

Setelah diuraikan mengenai kasus posisi dan landasan teori pada bab sebelumnya, pada bab ini penulis akan mencoba menganalisa beberapa hal terkait dengan penelitian mengenai pertimbangan dasar hukum hakim sudah tepat dilihat dari ilmu perundang-undangan pada kasus putusan Nomor 450/Pdt.G/2012 / Pn.Jkt.Bar.

Dalam putusannya, telah disebutkan dengan jelas bahwa Penggugat dalam hal ini PT Bangun Karya Peratama atas gugatannya meminta pembatalan Perjanjian dikabulkan, bahkan Perjanjian tersebut dianggap melanggar ketentuan Pasal 31 Undang-Undang Nomor 24 Tahun 2009. Hal ini berimbas kepada seluruh sektor bisnis di Indonesia yang menjadi lebih hati-hati dengan adanya putusan MA tersebut.

"Bahwa perjanjian yang dibuat parah pihak ditandatangani pada tanggal 30 Juli 2010, dibuat setelah diundangkannya Undang-Undang Nomor 24 Tahun 2009 tertanggal 9 Juni 2009 yang mensyaratkan harus dibuat dalam Bahasa Indonesia; Bahwa faktanya Loan Agreement tersebut tidak dibuat menggunakan Bahasa Indonesia, hal ini membuktikan bahwa perjanjian yang dibuat para pihak bertentangan dengan ketentuan Pasal 31 ayat (1) Undang-Undang Nomor 24 Tahun 2009 sehingga dengan 
demikian perjanjian/Loan Agreement a quo merupakan perjanjian yang dibuat berdasarkan sebab yang terlarang, sehingga sesuai ketentuan Pasal 1335 juncto Pasal 1337 KUHPerdata perjanjian tersebut batal demi hukum". 16)

Jika dilihat lebih dalam, syarat sahnya Perjanjian sesuai dengan yang diatur dalam Pasal 1320 KUHPerdata memang ada 4 (empat), yaitu:

1. Kesepakatan mereka yang mengikat dirinya;

2. Kecakapan untuk membuat suatu perikatan;

3. Suatu hal tertentu;

4. Suatu sebab yang halal;

Bahwa, syarat pada angka satu dan angka dua tersebut merupakan syarat Non Essensial subyektif, yang apabila tidak dipenuhi maka perjanjian tersebut berakibat dapat dibatalkan, sedangkan syarat pada angka tiga dan angka empat tersebut adalah merupakan syarat Essensial/Objektif, yang apabila tidak dipenuhi maka berkibat perjanjian tersebut batal demi hukum.

Tetapi apa yang sebenarnya dimaksudkan dengan suatu sebab yang halal yaitu bahwa sesuatu sebab dalam perjanjian tidak boleh bertentangan dengan undangundang, kesusilaan dan ketertiban umum.

Perlu dibedakan secara tegas antara sebab dan motif. Motif adalah alasan yang mendorong batin seseorang untuk melakukan sesuatu hal. Dalam hukum, motif adalah tidak penting. Sebab adalah tujuan dari perjanjian. Misalnya, Sebab dalam utang piutang dengan bunga adalah bahwa pihak yang satu ingin mendapatkan uang, sedangkan pihak lain menerima bunga. Sahnya causa (sebab) dari suatu perjanjian ditentukan pada saat perjanjian dibuat. Hal ini ternyata dalam arrest H.R 6 Januari 1922, di mana setelah terjadi penjualan pohon-pohon, keluar suatu larangan penebangan pohon. Kenyataan ini yang timbul kemudian tidak dapat mengganggu causa (sebab) dari perjanjian :

${ }^{16)}$ Putusan Mahkamah Agung Nomor 1572 K/Pdt/2015 
1. Perjanjian tanpa sebab. Perjanjian adalah tanpa sebab, jika tujuan yang dimaksud oleh para pihak pada waktu dibuat perjanjian tidak akan tercapai. Contohnya : para pihak mengadakan mengadakan novasi atas suatu perikatan yang tidak ada.

2. Perjanjian dengan sebab palsu. Yang dimaksud dengan sebab palsu adalah suatu sebab yang diadakan oleh para pihak untuk menyelubungi sebab yang sebenarnya.

3. Perjanjian dengan sebab tidak halal. Sebab tidak halal adalah sebab yang bertentangan dengan undang-undang, ketertiban umum, dan kesusilaan. Dalam hal ini hendaknya dibedakan dengan motif.

\section{Contoh :}

Jika A menyediakan uang bagi B untuk dipergunakan berjudi, di mana B berkewajiban membayar bunga $25 \%$ sebulan sebagai ganti ruginya, maka perjanjian tersebut mengandung causa tidak halal. Tapi jika seseorang meminjam uang dan mempergunakan uang tersebut untuk berjudi, tidak dapat dikatakan bahwa causanya tidak halal, karena maksud penggunaan uang tersebut untuk berjudi merupakan motif peminjaman uang.

Yang menjadi titik berat dalam kasus antara PT Bangun Karya Pratama dengan Nine AM. Ltd adalah syarat mengenai suatu sebab yang halal. Menurut Mahkamah Agung, Pelanggaran terhadap Pasal 31 Undang-Undang Nomor 24 Tahun 2009 tentang Bendera, Bahasa, dan Lambang Negara serta Lagu Kebangsaan merupakan suatu sebab yang tidak halal memiliki arti yang sangat luas kerena didalamnya terdapat unsur melanggar undang-undang, kesusilaan dan ketertiban umum.

Berkaitan denga kasus antara PT Bangun Karya Pratama dengan Nine AM. Ltd sebetulnya yang menjadi permasalahan bukan kerena sebab yang tidak halal, kerena sebabnya adalah Perjanjian Pinjam meminjam yang sudah lama ada di Indonesia. Tetapi melanggar formalitasnya yang merupakan bukti tertulis dibuat dalam bentuk Bahasa Inggris. 
Di dalam asas kebebasan berkontrak yang dijelaskan melalui rumusan Pasal 1338 KUHPerdata menyebutkan bahwa semua perjanjian yang dibuat secara sah, berlaku sebagai Undang-Undang bagi mereka yang membuatnya dan di dalam ayat (3) pasal 1320 KUHPerdata disebutkan persetujuan harus dilaksanakan dengan itikad baik. Pengertian ini berkaitan dengan asas pacta sunt servanda yang artinya bahwa perjanjian tersebut harus dilaksanakan.

Selain itu tidak disebutkan pelanggaran sangsi pada Pasal 40 Undang-Undang Nomor 24 Tahun 2009 tentang Bendera, Bahasa, dan Lambang Negara serta Lagu Kebangsaan yang menimbulkan banyak penafsiran terkait Undang-Undang ini. Salah satunya adalah surat kemekumham yang menyatakan bahwa perjanjian privat komersial (private commercial agreement) dalam bahasa Inggris tanpa disertai versi bahasa Indonesia tidak melanggar persyaratan kewajiban.

Terdapat penjelasan terkait pelaksanaan Pasal 31 Undang-Undang Nomor 24 Tahun 2009 tentang Bendera, Bahasa, dan Lambang Negara serta Lagu Kebangsaan, Menteri Hukum dan HAM, Patrialis Akbar. Melalui suratnya bernomor M.HH.UM.01.01-35 perihal "Permohonan Klarifikasi atas implikasi dan pelaksanaan UU No. 24 Tahun 2009”, Patrialis menyatakan perjanjian privat komersial (private commercial agreement) dalam bahasa Inggris tanpa disertai versi bahasa Indonesia tidak melanggar persyaratan kewajiban seperti ditentukan Undang-Undang tersebut.

Kata-kata "tidak melanggar persyaratan kewajiban" bahkan ditegaskan dengan menebalkan huruf dan diberi garis bawah. Dengan demikian, perjanjian yang dibuat dengan versi bahasa Inggris tetap sah atau tidak batal demi hukum atau tidak dapat dibatalkan. Patrialis beralasan, implementasi Pasal 31 tersebut menunggu sampai dikeluarkannya Peraturan Presiden. Memang, dalam Pasal 40 Undang-Undang Nomor 24 Tahun 2009 tentang Bendera, Bahasa, dan Lambang Negara serta Lagu Kebangsaan disebutkan, ketentuan lebih lanjut mengenai penggunaan bahasa 
Indonesia sebagaimana dimaksud dalam Pasal 26 sampai dengan Pasal 39, diatur dalam Peraturan Presiden. ${ }^{17)}$

"Bahasa Indonesia wajib digunakan dalam nota kesepahaman atau perjanjianyang melibatkan lembaga negara, instansi pemerintah Republik Indonesia, lembaga swasta Indonesia atau perseorangan warga negara Indonesia."

Apabila pasal tersebut ditafsirkan secara gramatikal maka jelas diatur bahwa perjanjian harus dibuat dalam bahasa Indonesia. Hal selanjutnya yang harus dikaji adalah jenis perjanjian yang harus menggunakan Bahasa Indonesia.

Berdasarkan penjelasan undang-undang Pasal 31 (1), yang dimaksud dengan perjanjian dalam pasal tersebut adalah, termasuk perjanjian internasional, yaitu setiap perjanjian di bidang hukum publik yang diatur oleh hukum internasional, dan dibuat oleh pemerintah dan negara, organisasi internasional, atau subjek hukum internasional lain. Perjanjian internasional ditulis dalam bahasa Indonesia, bahasa negara lain, dan/atau bahasa Inggris.

Sehingga segala jenis perjanjian juga termasuk perjanjian dalam hukum pulik internasional harus menggunakan bahasa Indonesia apabila melibatkan lembaga negara, instansi pemerintah Republik Indonesia, lembaga swasta Indonesia atau perseorangan warga negara Indonesia, organisasi internasional, atau subjek hukum internasional lainnya.

Majelis Hakim dalam putusannya tersebut mengenyampingkan adanya surat dari Menteri Hukum dan Hak Asasi Manusia Republik Indonesia, No. M.HH.UM.01.01.35 tanggal 28 Desember 2009, perihal: Klarifikasi atas implikasi dan pelaksanaan Undang-Undang Nomor 24 Tahun 2009 tentang Bendera, Bahasa, dan Lambang Negara serta Lagu Kebangsaan. Dalam surat tersebut Menteri Hukum dan HAM berpendapat penggunaan Bahasa Inggris pada perjanjian tidak melanggar syarat formil yang ditentukan dalam Undang-Undang Nomor 24 Tahun 2009 tentang

17) hukumonline.com, “Wajibkah Membuat Kontrak dalam Dua Bahasa Jika Melibatkan Pihak Asing?" (On-Line), tersedia di http://www.hukumonline.com/klinik/detail/lt4dd480ffe6cb1/wajibkahmembuat-kontrak-dalam-dua-bahasa-jika-melibatkan-melibatkan-pihak-asing- (16 Desember 2017) 
Bendera, Bahasa, dan Lambang Negara serta Lagu Kebangsaan sampai dikeluarkannya Peraturan Presiden. Akan adanya Peraturan Presiden tersebut sebagaiman termuat dalam Pasal 40 Undang-Undang Nomor 24 Tahun 2009 tentang Bendera, Bahasa, dan Lambang Negara serta Lagu Kebangsaan, yaitu "ketentuan lebih lanjut mengenai penggunaan Bahasa Indonesia sebagaimana dimaksud dalam Pasal 26 sampai dengan Pasal 39 diatur dalam Peraturan Presiden."

Majelis Hakim dalam pertimbangannya menyatakan, peraturan presiden tersebut nantinya tidak dapat melumpuhkan kata-kata "wajib" sebagaimana tercantum dalam Pasal 31 ayat (1) UU Bahasa, karena Peraturan Presiden mempunyai kedudukan yang lebih rendah dari UU.

Demikian pula dengan surat dari Menteri Hukum dan Ham tersebut, tidak dapat mengalahkan ketentuan sebagaimana diatur dalam UU. Dengan demikian karena Loan Agreement tersebut tidak dibuat dalam bahasa indonesia maka bertentangan dengan UU Bahasa sehingga merupakan perjanjian terlarang karena dibuat dengan sebab yang terlarang.

Jika terjadi hal seperti ini tentu saja Pasal 40 Undang-Undang Nomor 24 Tahun 2009 tentang Bendera, Bahasa, dan Lambang Negara serta Lagu Kebangsaan tidak mempunyai kekuatan apapun. Pasal ini sendiri menyatakan ketentuan lebih lanjut diatur dalam Peraturan Presiden untuk melindungi kata-kata "wajib" Majelis hakim mengabaikan Pasal 40 Undang-Undang Nomor 24 Tahun 2009 tentang Bendera, Bahasa, dan Lambang Negara serta Lagu Kebangsaan ini yang seharusnya membuat perjanjian tidak bertentangan dengan hukum.

Kehendakpembuat undang-undang untuk tidak membuat batal suatu perjanjian yang dibuat hanya dalam Bahasa asing atau Inggris telah ditegaskan pula dalam undang-undang yang dibuat setelah berlakunya Undang-Undang Nomor 24 Tahun 2009, yaitu Undang-Undang Nomor 2 Tahun 2014 Tentang Perubahan Atas UndangUndang Nomor 30 Tahun 2004 Tentang Jabatan Notaris tersebut tidak memberikan sanksi batal bagi suatu perjanjian yang dibuat di hadapan seorang notaris dalam bahasa asing (termasuk bahasa Inggris). Pasal 43 ayat (3) Undang-Undang Nomor 2 
Tahun 2014 Tentang Perubahan Atas Undang-Undang Nomor 30 Tahun 2004 Tentang Jabatan Notaris menyatakan:

"Jika para pihak menghendaki Akta dapat dibuat dalam bahasa asing";

Berdasarkan Pasal 1313 KUHPerdata Perjanjian atau kontrak adalah suatu peristiwa di mana seorang atau satu pihak berjanji kepada seorang atau pihak lain atau di mana dua orang atau dua pihak itu saling berjanji untuk melaksanakan suatu hal. Pada pasal ini tidak disebutkan suatu perjanjian harus berupa tertulis atau nota kesepahaman yang hanya merupakan barang bukti bahwa telah terjadi perikatan tersebut. Kedua belah pihak baik penggugat maupun tergugat telah setuju dan menjalankan kewajibannya masing-masing dalam menjalankan Perjanjian yang dimana pihak yang satu memberikan pinjaman dan pihak yang lain membayar pinjaman cicilan.

Apakah suatu perjanjian harus dilakukan secara tertulis? Pada dasarnya, perjanjian tidak harus dibuat secara tertulis, kecuali diharuskan oleh peraturan perundangundangan, misalnya:

1. Perjanjian Kerja Waktu Tertentu dibuat secara tertulis, sesuai dengan Pasal 57 Undang-Undang No. 13 Tahun 2003 tentang Ketenagakerjaan. Sebagaimana diatur pada Pasal tersebut, Perjanjian Kerja Waktu Tertentu yang tidak dibuat secara tertulis akan memiliki akibat hukum yaitu berubahnya status Perjanjian menjadi Perjanjian Waktu Tidak Tertentu; dan

2. Perjanjian lain yang memerlukan Perjanjian yang dibuat secara tertulis adalah Perjanjian atas pemindahan hak atas saham yang dilakukan dengan akta pemindahan hak, sesuai Pasal 56 Undang-Undang No. 40 Tahun 2007 tentang Perseroan Terbatas.

Dalam hal perjanjian pinjam meminjam tidak diatur untuk dibuat dalam bentuk tertulis sehingga di perbolehkan bilah hanya menggunakan lisan saja, dalam hal ini kedua belah pihak telah setuju dan sepakat sebagaimana di atur dalam pasal 1338 KUHPerdata yang berbunyi Semua persetujuan yang dibuat sesuai dengan undangundang berlaku sebagai undang-undang bagi mereka yang membuatnya. Persetujuan 
itu tidak dapat ditarik kembali selain dengan kesepakatan kedua belah pihak, atau karena alasan-alasan yang ditentukan oleh undang-undang. Persetujuan harus dilaksanakan dengan itikad baik.

Perjanjian yang dibuat secara lisan/tidak tertulis pun tetap mengikat para pihak, dan tidak menghilangkan, baik hak dan kewajiban dari pihak yang bersepakat. Namun, untuk kemudahan pembuktian, acuan bekerja sama dan melaksanakan transaksi, sebaiknya dibuat secara tertulis. Hal ini juga dimaksudkan, agar apabila terdapat perbedaan pendapat dapat kembali mengacu kepada perjanjian yang telah disepakati. Hal ini menunjukan bahwa perjanjian dalam bentuk tertulis hanya merupakan bagian dari pembuktian lalu apakah nota kesepahaman yang dibuat secara tertulis diangap batal demi hukum juga dapat membatalkan ini dari perjanjian tersebut yang sedangkan perjanjiannya itu sendiri memenuhi semua syarat perjanjian sesuai dengan 1320 KUHPerdata.

Selain itu putusan MA ini juga dapat menyebabkan halalnya itikad tidak baik yang dilakukan oleh Penggugat putusan ini dapat berpengaru bagi para pengusaha yang dimana perjanjian yang rentan seperti terjadi pada kasus antara Nine AM Ltd dengan PT Bangun Karya Pratama dapat terjadi penyalahgunaan keadaan oleh salah satu Pihak, sehingga para penanam modal asing akan yang kurang tau akan hukum positif Indonesia seperti Nine AM Ltd akan dimanfaatkan oleh subjek hukum yang tidak beretikat baik. Tentu saja hakim tidak dapat membatalkan perjanjian hanya kerena buktinya yang tidak benar, tetapi hakim dapat membatalkan bukti perjanjian tertulis tetapi tidak seharusnya membatalkan essensi dari perjanjian itu sendiri.

Hal tersebut sangat memicu terjadinya penyalahgunaan keadaan oleh PT Bangun Karya Pratama yang memanfaatkan kelemahan lawan untuk melakukan penyalahgunaan keadaan sehingga Nine AM Ltd di eksploitasi dan digugat dengan dasar penggunaan Bahasa dalam Perjanjian.

\section{PENUTUP}

\section{A. Kesimpulan}


Pada Jurnal ini maka penulis dapat mengemukakan kesimpulan yang di dapat dari permasalahan yang terdapat dalam jurnal yang berjudul "Pembatalan Pada Perjanjian Yang Tidak Menggunakan Bahasa Indonesia (Studi Kasus Putusan Nomor 450/Pdt.G/2012 / Pn.Jkt.Bar)". Dalam hal ini penulis dapat mengambil sebuah kesimpulan bahwa di dalam permasalahan ini bahwa pada dasarnya dengan adanya Pasal 31 Undang-Undang Nomor 24 Tahun 2009 tentang Bendera, Bahasa, dan Lambang Negara serta Lagu Kebangsaan tidak dapat serta merta membatalkan suatu perjanjian karena hal tersebut tidak bertentangan dengan syarat sahnya perjanjian yang terkandung di dalam Pasal 1320 KUHPerdata tetapi hakim dalam memutus perkara dapat membatalkan perjanjian tertulis yang merupakan bukti dalam persidangan itu sendiri tetapi tidak dapat membatalkan perjanjian yang telah disetujui oleh ke dua belah pihak. Jadi pemenuhan perjanjian harus tetap dipenuhi dan dilaksanakan sesuai perjanjian yang telah disepakatai karena hal ini sesuai dengan asas perjanjian yaitu asas Pacta Sunt Seravanda.

\section{B. Saran}

Dari kesimpulan yang telah ditulis oleh penulis, maka dalam kesempatan kali ini penulis ingin memberikan saran dalam penyelesaian permasalahan ini sebagai berikut:

1. Ada baiknya hakim dalam memutus perkara lebih hati-hati dan bijaksana dan tidak memihak terhadap siapapun dalam melaksanakan putusannya.

2. Ada baiknya Pasal 31 Undang-Undang Nomor 24 Tahun 2009 tentang Bendera, Bahasa, dan Lambang Negara serta Lagu Kebangsaan diperjelas lebih lanjut atau diatur lebih lanjut dengan membuat Perpres sebagaimana di tetepakan pada Pasal 40 Undang-Undang Nomor 24 Tahun 2009 tentang Bendera, Bahasa, dan Lambang Negara serta Lagu Kebangsaan.

3. Etikat baik harus dijunjung tinggi dalam hukum perdata dalam kasus Nomor 450/Pdt.G/2012/PN Jkt.Bar. yang dimana Penggugat untuk menghidar dari 
memenuhi prestasinya dengan cara melakukan gugatan pembatalan perjanjian yang telah disepakati dan dilaksanakan oleh ke dua belah pihak.

\section{DAFTAR PUSTAKA}

Indonesia, Kitab Undang-Undang Hukum Perdata,

Indonesia, Undang-Undang Nomor 24 Tahun 2009 tentang Bendera, Bahasa dan Lambang Negara Serta Lagu Kebangsaan

Komariah. Hukum Perdata, (Malang, UMM PRESS, 2017)

Mahmud Marzuki, Peter. Penelitian Hukum, (Jakarta: Prenada Media Group,2005)

Miru, Ahmad. Hukum Perikatan, (Jakarta; RajaGrafindo Persada, 2014)

Mukti Fajar ND dan Yulianto Achmad, Op. Cit

Peter Mahmud Marzuki,Penelitian Hukum, (Jakarta: Prenada Media

Group,2016)

Putusan Mahkamah Agung Nomor 1572 K/Pdt/2015

Subekti, Hukum Perjanjian, (Jakarta: Intermasa, 2005)

Subekti, Pokok-Pokok Hukum Perdata, (Jakarta; Intermasa, 2001).

Subekti. Aneka Perjanjian, (Bandung: Citra Aditya Bakti, 1995) 